\title{
EFFECTS OF FOLIC ACID INTAKE DURING PREGNANCY WHOSE MOTHER WAS EXPOSED TO CIGARETTE SMOKE TOWARDS BRAIN NEURONS APOPTOSIS INDEX AND QUANTITY OF MICE (Mus musculus) OFFSPRING
}

\author{
Nyna Puspita Ningrum ${ }^{1}$, Hermanto Tri Joewono ${ }^{2}$ Widjiati $^{3}$ \\ ${ }^{1}$ Master Program of Reproductive Health Science, ${ }^{2}$ Department of Obstetrics and Gynecology, Faculty of Medicine, \\ ${ }^{3}$ Department of Embryology, Faculty of Vetenary Medicine, Universitas Airlangga, Surabaya
}

\begin{abstract}
ABSTRAK
Asam folat mengandung 5-Methyltetrahydrofolate (5-MTHF) dan merupakan salah satu antioksidan yang dapat digunakan untuk menghambat reaksi yang terjadi akibat paparan asap rokok. Asam folat dapat menghambat kadar Reactive Oxygen Species (ROS) sehingga mampu mengurangi terjadinya apoptosis neuron. Tujuan penelitian ini adalah untuk mengetahui pengaruh pemberian asam folat selama kebuntingan yang induknya dipapar asap rokok terhadap indeks apoptosis dan jumlah neuron otak mencit (Mus musculus) baru lahir. Metode penelitian ini menggunakan studi eksperimental laboratorium dengan desain penelitian post test only control group design, subyek penelitian menggunakan 24 ekor mencit betina yang dibagi dalam 4 kelompok yaitu 1 kelompok kontrol dan 3 kelompok perlakuan. Pengambilan sampel menggunakan simple random sampling. Setiap kelompok terdiri atas 6 hewan coba. K1: kelompok kontrol hanya diberikan aquades selama kebuntingan, K2: kelompok yang diberikan asam folat secara oral pada usia kebuntingan 0-17 hari sebanyak 0,06 mg/hari/mencit, K3: kelompok yang diberikan paparan asap rokok kretek pada umur kebuntingan hari ke 7-17 sejumlah 2 batang rokok/hari, K4: kelompok yang diberikan asam folat secara oral pada usia kebuntingan 0-17 hari sebanyak 0,06 mg/hari/mencit dan paparan asap rokok kretek pada umur kebuntingan hari ke 7-17 sejumlah 2 batang rokok/hari. Hasil penelitian menunjukkan ada perbedaan signifikan pada semua variabel. Pada indeks apoptosis terdapat perbedaan signifikan antara $K 1$ dengan $K 3, K 2$ dengan $K 3, K 3$ dengan $K 4$, perbedaan signifikan pada jumlah neuron antara K1 dengan K3, K2 dengan K3, K2 dengan K4. Kesimpulan penelitian ini adalah terdapat perbedaan indeks apoptosis yang signifikan antara keempat kelompok penelitian, dan terdapat perbedaan jumlah neuron yang signifikan antara keempat kelompok penelitian. (FMI 2018;54:34-40)
\end{abstract}

Kata kunci: Paparan asap rokok; asam folat; indeks apoptosis; jumlah neuron

\begin{abstract}
Folic acid contains 5-methyltetrahydrofolate (5-MTHF), one of antioxidants that can be used to inhibit reaction caused by cigarette smoke exposure. Folic acid is able to inhibit the levels of Reactive Oxygen Species (ROS) so as to reduce the occurrence of neuronal apoptosis. The objectives of this study was to determine the effect of folic acid intake during pregnancy whose mother was exposed to cigarette smoke on brain neurons apoptosis index and quantity of mice (Mus musculus) offspring. This study was an experimental laboratory study with posttest-only control group design. The subjects were 24 female mice divided into 4 groups consisting of one control group and three treatment groups. Sampling used simple random sampling, each group consisting of 6 animals. Control group 1 was not given treatment during pregnancy, group 2 was given with folic acid orally on days 0-17 of gestational age as much as $0.06 \mathrm{mg} /$ day/mice. Group 3 was given with cigarette smoke exposure on days 7-17 of gestational age, amounting to 2 cigarettes/day. Group 4 was given with cigarette smoke exposure on days 7-17 of gestational age, amounting to 2 cigarettes/day and folic acid orally on days 0-17 of gestational age as much as $0.06 \mathrm{mg} /$ day/mice. The result showed significant differences in all variables. In neurons apoptosis index, there were significant differences between groups 1 and 3, groups 2 and 3, groups 3 and 4, significant differences in the quantity of neurons between groups 1 and 3, groups 2 and 3, groups 2 and 4. The study concluded that there were significant difference in neural apoptosis index between all groups, and there were also significant differences in the quantity of neurons between all groups. (FMI 2018;54:34-40)
\end{abstract}

Keywords: Cigarette smoke exposure; folic acid; apoptosis index; the quantity of neurons

Correspondence: Nyna Puspita Ningrum, Master Program of Reproductive Health Science, Faculty of Medicine, Universitas Airlangga, Jl. Prof Dr Moestopo 47, Surabaya, Indonesia 60131. Phone: 031-5501617.

Email: nynapuspita@gmail.com

\section{INTRODUCTION}

The number of smokers in Indonesia increases year by year. Data of General Agreement on Trade in Service
(GATS) showed that the prevalence of smokers in Indonesia was $34.8 \%$. Indonesia has the highest number of male smokers in the world (Ministry of Health 2015). These data show that Indonesia is facing a critical 
period with the number of smokers which exceeding other countries. Large number of smokers result in the number of people exposed to cigarette smoke to increase. Riskesdas in 2013 stated that the number of active smokers aged 10 years and older were 57,750,592 people. This amount consists of $56,860,475$ male smokers and 1,890,135 female smokers (Ministry of Health 2015). These numbers show that women are more exposed to smoke as compared to men. There are $59.1 \%$ of all children under five exposed to cigarette smoke. It indicates that over half of the group whose exposed to cigarette smoke are the most vulnerable groups, namely women and children under five.

Pregnant women have a high risk of exposure to cigarette smoke due to their pregnancy. Pregnant women as passive smokers are at risk of low birth weight (LBW) (Ramadhan 2012). Exposure to cigarette smoke can reduce $20 \%$ of folic acid level in the body, so that exposure to cigarette smoke in pregnancy causes impaired fetal growth in the womb (Wickstörm 2007). Smoking or passive smoking is associated with fetal growth retardation, increased perinatal and infant mortality and morbidity. Women who have smoking habits are also at risk of developing prenatal deaths, or Sudden Infant Death Syndrome (SIDS). Exposure to cigarette smoke activates free radicals and increase of homocysteine which will damage three major molecular components of cell body which is lipid, protein, and deoxyribo nucleat acid (DNA). Damage that occurs in each lipid oxidation and the basic process of cells DNA oxidation will disrupt the integrity of the cell, so that it will cause cell death.

Apoptosis is a form of cell death through a genetic mechanism or breakage or chromosomal fragmentation of DNA. Apoptosis also occurs during normal development of the central nervous system. Receptor blockade of N-methyl-D-aspartame (NMDA) glutamate few hours after the end of fetal development or early life of neonates can lead to wide spread of neurodegeneration apoptosis in developing fetal brain. Neurotransmitter glutamate which acts on NMDA receptors can control the lives of neurons.

Neuronal cells are important element which have functions to receive, deliver, and process the stimuli. These cells serves to the originator of a particular cell activity as well as the release of neurotransmitters and other molecules that convey information. The development of neuronal cells would affect the functioning of the brain so that necessary preventive or reactions inhibitor which could decrease brain function.

One of antioxidants that can be used to inhibit reactions that occur upon cigarette smoke exposure is folic acid.
Folic acid contains 5-Methyltetrahydrofolate (5-MTHF) which can inhibit the levels of Reactive Oxygen Species (ROS) that can reduce the occurrence of apoptosis. It can help to improve fetal brain development and function. Therefore, folic acid is necessary for essential nutrients addition for brain growth.

Folic acid can be administered through the nutrition of the mother. Pregnant women need more nutritional intake compared to others. The high demand for folic acid required by pregnant women is necessary to reduce fetus risk for experiencing Neural Tube Defect (NTD). NTD is a disorder that occurs in the nervous system of the fetus contingentaly. Pregnant women who take folic acid within adequate levels can reduce fetal risk of NTD around $70-80 \%$. Therefore, pregnant women require 600 mcg of folic acid daily to meet those needs, which is 200 mcg higher compared to women who are not pregnant.

According to Istiadjid (2004), folic acid deficiency causes the number of brainpan cells undergo apoptosis and necrosis increase. A study conducted by Ginting (2013) showed an intellectual decrease in mice offspring that was born from pregnant mice parents exposed to cigarette smoke. Various facts about the effects and adverse effects of cigarette smoke exposure in pregnancy especially towards neurons apoptosis index and quantity of newborn currently is still limited. Therefore, this study was conducted to determine the effect of folic acid intake during pregnancy whose mother was exposed to cigarette smoke towards neurons apoptosis index and quantity. Due to ethical problem, this study was conducted on mice offspring brain.

\section{MATERIALS AND METHODS}

This was an experimental laboratory study with post test-only control group research design. The research was conducted on experimental animals at Pathology Laboratory of Faculty of Veterinary Medicine, Universitas Airlangga. This study was conducted from September 16 to October 13, 2016. The samples were pregnant female mice (Mus musculus) aged 8-10 weeks, weighing 20-25 grams. On gestation day 0 , the mice were given with folic acid until day 17 . On day 7 to 17 , they were given with exposure to cigarette smoke. Then, immediately after the labor, the brain tissue of the mice offspring were taken for examination.

This study used randomized sampling (simple random sampling). Randomization was directly performed since samples were taken from mice which met inclusion and exclusion criteria that were considered fairly homogeneous. The samples were divided into 4 groups consisting 
of 1 control group and 3 treatment groups. Each group consisted of 6 animals. Fertilization performed on mice used, K1 groups: control group that were given distilled water, K2 groups: group given with folic acid orally on days $0-17$ of gestational age as much as $0.06 \mathrm{mg} /$ day/mice, K3 groups: group given with cigarette smoke exposure of 2 cigarettes/day on gestation days 7-17, K4 groups: group given with folic acid orally on days $0-17$ of gestational age as much as $0.06 \mathrm{mg} /$ day/mice and cigarette smoke exposure of 2 cigarettes/day on gestation days 7-17.

The data were tested with normality data test using Shapiro-Wilk statistical test to determine whether there was the effect of folic acid intake in pregnant mice exposed to cigarette smoke towards apoptosis index and the number of neurons. If data were normally distributed, oneway ANOVA was used. Whereas, if data were not normally distributed, Kruskal-Wallis was used. Normaly distributed data were analyzed using Pearson correlation test. Post hoc Mann-Whitney test was performed if the data were not normally distributed. Significance limit was $\mathrm{p}<0.05$ with $95 \%$ confidence interval.

\section{RESULTS}

Research data were conducted with Shapiro-Wilk normality test to determine the effects of folic acid in pregnant mice exposed to cigarette smoke towards neurons apoptosis index and number. The data were not normally distributed, so we assessed using KruskalWallis test followed by Mann-Whitney post-hoc test. Significance limit was $\mathrm{p}<0.05$ with $95 \%$ confidence interval.

\section{Effects of folic acid intake during pregnancy whose mother was exposed to cigarette smoke towards brain neurons apaptosis index of mice (Mus musculus) offspring}

Data analysis on brain neuron apoptosis index of mice offspring was performed using normality test with two methods, Kolmogorov-Smirnov and Shapiro-Wilk. The data distribution is considered normal if the value of $\mathrm{p}>0.05$. Table 1 shows that the data on neurons apoptosis index of mice (Mus musculus) offspring are not normally distributed which is indicated with $\mathrm{p}<0.05$ $(\mathrm{p}=0.003)$. Thus, the hypothesis test used in this study was Kruskal-Wallis test to determine the differences of the entire groups. Furthermore, Mann-Whitney post-hoc analysis was used to observe the difference between the 2 groups.

Table 2. Kruskal-Wallis test results on brain neurons apoptosis index of mice offspring (Mus musculus)

\begin{tabular}{cc}
\hline Variable & $\begin{array}{c}\mathrm{p} \\
\text { Value }\end{array}$ \\
\hline $\begin{array}{c}\text { Apoptosis } \\
\text { index }\end{array}$ & $0.003^{*}$ \\
*Mean difference (significant if $\mathrm{p}<0.05$ )
\end{tabular}

Table 2 shows the value of $\mathrm{p}<0.05(\mathrm{p}=0.003)$, indicating there is significant mean difference between the entire groups or significant brain neurons apoptosis index of mice offspring (Mus musculus).

Apoptosis in pathological states was characterized by cell death produced by multiple stimulation in the form of cell damage. Apoptosis is a homeostatic mechanism to maintain the population of cells in the network, as a reaction against cell damage by disease.

Table 3. Mann-Whitney post-hoc test results on brain neurons apoptosis index of mice offspring

\begin{tabular}{ccccc}
\hline Samples & K1 & K2 & K3 & K4 \\
\hline K1 & - & 0.872 & $0.004^{*}$ & 0.376 \\
K2 & 0.872 & - & $0.004^{*}$ & 0.091 \\
K3 & $0.004^{*}$ & $0.004 *$ & - & $0.010^{*}$ \\
K4 & 0.376 & 0.091 & $0.010^{*}$ & - \\
\hline *Mean difference & & &
\end{tabular}

Table 3 shows the significant difference with the value of $\mathrm{p}<0.05$ between K1 with K3 ( $\mathrm{p}=0.004)$, K2 with K3 $(\mathrm{p}=0.004)$, and $\mathrm{K} 3$ with $\mathrm{K} 4(\mathrm{p}=0.010)$. The results in Table 3 indicated that there were significant differences between the group given cigarette smoke exposure and the control group (K3 and K1), the group given folic acid with the group given cigarette smoke exposure (K2 and $\mathrm{K} 3$ ), and the group given cigarette smoke exposure with the group given cigarette smoke exposure and folic acid (K3 and K4).

The data analysis results showed that the brain neurons apoptosis index of mice (Mus musculus) offspring in K4 was lower than that in $\mathrm{K} 3$. K3 brain neurons apoptosis index of mice offspring increased dramatically than those in $\mathrm{K} 2$, and $\mathrm{K} 1$ brain neurons apoptosis index of mice offspring was lower than that in K3. The administration of folic acid during pregnancy may decrease brain neurons apoptosis index of mice offspring under cigarette smoke exposed conditions. 
Table 1. Data normality test results on brain neurons apoptosis index of mice offspring

\begin{tabular}{ccccccc}
\hline & \multicolumn{3}{c}{ Kolmogorov-Smirnov } & \multicolumn{3}{c}{ Shapiro-Wilk } \\
\cline { 2 - 7 } & Statistics & $\mathrm{N}$ & $\mathrm{p}$ Value & Statistics & $\mathrm{N}$ & $\mathrm{p}$ Value \\
\hline Apoptosis index & 0.164 & 24 & 0.094 & 0.853 & 24 & $0.003^{*}$ \\
\hline *Normal distribution (significant if $\mathrm{p}>0.05)$ & & & & &
\end{tabular}

*Normal distribution (significant if $\mathrm{p}>0.05$ )

Table 4. Data normality test results on brain neurons quantity of mice offspring

\begin{tabular}{ccccccc}
\hline & \multicolumn{3}{c}{ Kolmogorov-Smirnov $^{\mathrm{a}}$} & \multicolumn{3}{c}{ Shapiro-Wilk } \\
\cline { 2 - 7 } & Statistics & $\mathrm{N}$ & $\mathrm{p}$ Value & Statistics & $\mathrm{N}$ & $\mathrm{p}$ Value \\
\hline $\begin{array}{l}\text { Neurons } \\
\text { quantity }\end{array}$ & 0.180 & 24 & 0.043 & 0.913 & 24 & $0.041^{*}$ \\
\hline * Normal distribution (significant if $\mathrm{p}>0.05)$ & & & & &
\end{tabular}

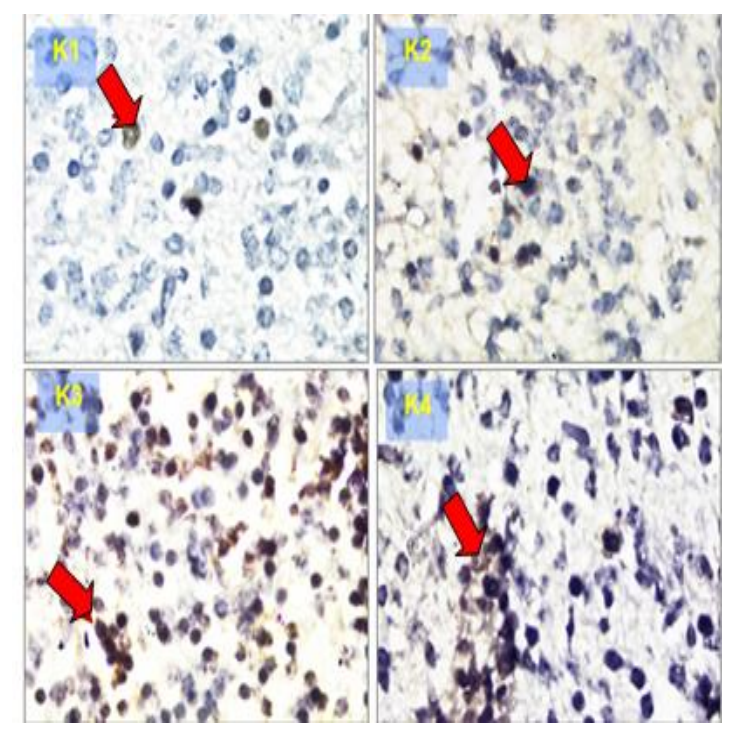

Fig. 1. Apoptosis in the brain of mice offspring using a light microscope with a magnification of 1000x. Neurogenic apoptosis cells were shown by stained dark brown neuronal cells.

The correlation between the 2 factors can be tested using Chi-Square test. We suggested whether the administration of folic acid during pregnancy whose mother was exposed to cigarette smoke had nothing to do with the brain neurons apoptosis index of mice offspring, or, on the contrary that the administration of folic acid during pregnancy whose mother was exposed to cigarette smoke is strongly associated with the neurons apoptosis index of mice offspring brain. To answer these presumptions, we used Chi-Square test. The results of Chi-Square test showed the value of $\mathrm{x}$ count $=13.655$ and $\mathrm{df}=3$ (which obtained the value of $\mathrm{x}$ table $=7.815$ ), indicating that there were correlations of folic acid intake during pregnancy whose mother was exposed to cigarette smoke on the brain neurons apoptosis index of mice offspring.
Effects of folic acid intake during pregnancy whose mother was exposed to cigarette smoke towards brain neurons quantity of mice (Mus musculus) offspring

Data analysis on the brain neuron quantity of mice offspring were performed normality test using two methods, which is Kolmogorov-Smirnov and ShapiroWilk. The data distribution was considered normal if the value of $\mathrm{p}>0.05$.

Table 4 shows that data on brain neurons quantity of mice offspring were not normally distributed so that the hypothesis test used was Kruskal-Wallis test and then proceed with the Mann-Whitney post-hoc analysis.

Table 5. Kruskal-Wallis test results on brain neuron quantity of mice (Mus musculus) offspring

\begin{tabular}{cc}
\hline Variable & $\begin{array}{c}\mathrm{p} \\
\text { Value }\end{array}$ \\
\hline $\begin{array}{l}\text { Neuron } \quad 0.002 * \\
\text { quantity }\end{array}$ & Mean difference (significant if $\mathrm{p}<0.05$ )
\end{tabular}

Table 5 shows the value of $\mathrm{p}<0.05$ ( $\mathrm{p}=0.002)$, indicating there was significant difference or significant mean on brain neurons quantity of mice offspring between each group. Furthermore, Mann-Whitney post-hoc test performed to determine the average number of brain neurons of mice offspring between different groups.

Fig. 2 shows that brain neurons quantity of mice offspring in the group given with smoke exposure only (K3) has the fewest number of neurons compared with the other groups (the number of neurons marked with yellow arrows). 


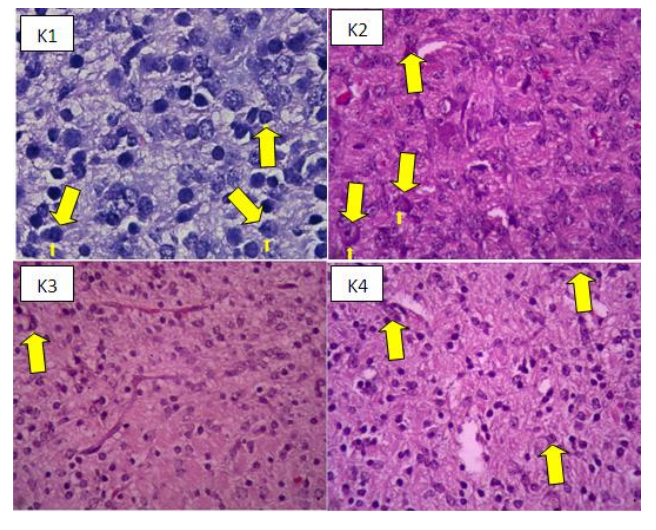

Fig. 2. Brain neurons quantity of mice offspring using Optilab viewer 2.2 with $400 x$ magnification. Neurons are cells that have nucleus with open faced type, which means that nucleus derivative or nucleolus is clearly visible and located in the middle.

Table 6. Mann-Whitney post-hoc test results on brain neurons quantity of mice offspring

\begin{tabular}{ccccc}
\hline Samples & K1 & K2 & K3 & K4 \\
\hline K1 & - & 0.261 & $0.010^{*}$ & 0.336 \\
K2 & 0.261 & - & $0.004^{*}$ & $0.004^{*}$ \\
K3 & $0.010^{*}$ & $0.004^{*}$ & - & 0.053 \\
K4 & 0.336 & $0.004^{*}$ & 0.053 & - \\
\hline *Mean difference & & &
\end{tabular}

The mean data analysis on brain neurons quantity of mice offspring using Mann-Whitney post-hoc test in table 6 shows a significant difference with value of $\mathrm{p}<0.05$ between $\mathrm{K} 2$ with $\mathrm{K} 4(\mathrm{p}=0.004), \mathrm{K} 2$ with $\mathrm{K} 3$ ( $\mathrm{p}=0.004)$ and $\mathrm{K} 1$ with $\mathrm{K} 3(\mathrm{p}=0.010)$.

The data analysis results showed that the brain neurons quantity of mice offspring in $\mathrm{K} 4$ was lower than that in K2. K3 brain neurons quantity of mice offspring had decreased dramatically than that in $\mathrm{K} 2$, and $\mathrm{K} 1$ brain neurons quantity of mice offspring was higher than that in K3. Administration of folic acid during pregnancy can increase the brain neurons quantity of mice (Mus musculus) offspring on the cigarette smoke exposed conditions.

Chi-square test was used to determine the correlation between the administration of folic acid during pregnancy whose mother was exposed to cigarrete smoke with the quantity of brain neurons of mice offspring. The results of Chi-Square test showed the value of $\mathrm{x}$ count $=$ 14.491 and $\mathrm{df}=3$ (which gives the value of $\mathrm{x}$ table $=$ 7.815), indicating there were linkages of folic acid administration during pregnancy whose mother was exposed to cigarette smoke on the brain neurons quantity of mice offspring.

\section{DISCUSSION}

\section{Effects of folic acid intake during pregnancy whose mother was exposed to cigarette smoke towards brain neurons apaptosis index of mice (Mus musculus) offspring}

The results showed that oral administration of folic acid to the mice (Mus musculus) mother on days 0-17 of gestational age as much as $0.06 \mathrm{mg} /$ day/mice (K2) was proven to lower the brain neurons apoptosis index of mice offspring compared with the control group (K1). The average value of the brain neurons apoptosis index of mice group that given folic acid (K2) was 7.58 and the average brain neurons apoptosis index of mice in the control group (K1) was 8.75. Oral administration of folic acid to mice on days $0-17$ of gestational age as much as $0.06 \mathrm{mg} / \mathrm{day} / \mathrm{mice}$ and exposured to cigarette smoke from days 7-17 of gestational age as much as 2 cigarettes/day (K4) was proven to lower the brain neurons apoptosis index of mice offspring compared to the mice that were exposured to cigarette smoke at the same dose (K3). The average value of the brain neurons apoptosis index of mice offspring that were given folic acid and were exposed to cigarette smoke group (K4) was 12.50 and the average value of brain neurons apoptosis index of mice offspring group that were exposured to cigarette smoke (K3) was 21.17.

Oral administration of folic acid to the mice mother on days $0-17$ of gestational age as much as 0.06 $\mathrm{mg} /$ day/mice according to data analysis using MannWhitney post-hoc test showed significant difference value in brain neurons apoptosis index of mice with $\mathrm{p}<0.05$ between K3 group with the control group (K1) $(\mathrm{p}=0.004)$, between the group given with folic acid (K2) with the group exposured to cigarette smoke (K3) $(\mathrm{p}=0.004)$, and between the group exposured to cigarette smoke (K3) with the group given with folic acid and exposured to cigarette smoke (K4) $(\mathrm{p}=0.010)$. This proved that the increase in the brain neurons apoptosis index of mice offspring could be treated with folic acid.

Previous studies showed that nicotine may also increase oxidative stress, damaging DNA, lipid peroxide, Reactive Oxygen Species (ROS) and neurons apoptosis (Mishra et al 2014). The imbalance of free radicals and Reactive Oxygen Species (ROS) and the antioxidant levels inside the body can increase oxidative stress that may have impact on the increase in neurons apoptosis. Folic acid is one of the antioxidants that contains 5methyltetrahydrofolate (5-MTHF) which can reduce the levels of homocysteine and decreased ROS and neuroral apoptosis index. 
Based on the results of Chi-square test that showed the value of obtained $x$ count was greater than the value of $x$ table (number $x$ count $=13.655>x$ table $=7.815$ ), this research proved the relevance or effects of folic acid intake during pregnancy whose mothers were given with cigarette smoke exposure towards the decrease in the brain neurons apoptotic index of mice offspring.

\section{Effect of folic acid intake during pregnancy whose mothers were exposed to cigarette smoke towards brain neurons quantity of mice (Mus musculus) offspring}

The results showed that the oral administration of folic acid to the mice on days 0-17 of gestational age as much as $0.06 \mathrm{mg} /$ day/mice $(\mathrm{K} 2)$ was proven to increase the brain neurons quantity of mice compared to the control group (K1). The average value of brain neurons quantity of mice group that given folic acid (K2) is 19.67 and the average value of brain neurons quantity of mice in the control group (K1) is 15.00. Oral administration of folic acid to the mice mother on days $0-17$ of gestational age as much as $0.06 \mathrm{mg} /$ day/mice and exposured to cigarette smoke from days 7-17 of gestation as many as 2 cigarettes/day (K4) were proven to increase the value of brain neurons quantity of mice offspring compared to the mice mothers exposured to cigarette smoke at the same dose (K3). The average value of brain neurons quantity of mice offspring group given with folic acid and exposed to cigarette smoke (K4) was 10.50 and the average value of brain neurons quantity of mice offspring group exposured to cigarette smoke (K3) was 4.83 .

Oral administration of folic acid to the mice mothers on days $0-17$ of gestational age as much as $0.06 \mathrm{mg} / \mathrm{day} /$ mice according to data analysis using Mann-Whitney post-hoc test showed significant difference value in brain neurons quantity of mice offspring with $\mathrm{p}<0.05$ among the group given with folic acid (K2) with the group exposured to cigarette smoke $(\mathrm{K} 3)(\mathrm{p}=0.004)$, the group given with folic acid (K2) with the group given with folic acid and exposured to cigarette smoke (K4) $(\mathrm{p}=0.004)$, the group exposured to cigarette smoke (K3) with the control group $(\mathrm{K} 1)(\mathrm{p}=0.010)$. This proved that the decrease in the brain neurons quantity of mice offspring can be treated with folic acid.

These results are consistent with a study done by Selhub et al (2009) which showed that folic acid plays a role in neurocognitive, regarding normal functioning of the brain when there is deficiency of this vitamin, that will cause dysfunction of neurologic, psychological and cause one-carbon metabolism disorders. Folic acid is also required for women within reproductive age, thus reducing the risk of birth defects in the neural tube, heart problems, cleft lip and urinary tract defects of the fetus (Lewis et al 1999). Folic acid is one of the antioxidants that contains 5-methyltetrahydrofolate (5MTHF) which can reduce the levels of ROS and homocysteine as well as increase the quantity of neuronal cells. This is in accordance with the test results that showed the obtained value of $\mathrm{x}$ count was greater than the value of $\mathrm{x}$ table (number $\mathrm{x}$ count $=14.491>\mathrm{x}$ table=7.815). This study proved the relevance or influence between administration of folic acid during pregnancy whose mothers were given with cigarette smoke exposure towards increased in the brain neurons quantity of mice offspring.

\section{CONCLUSION}

There was significant difference in the average value of brain neurons apoptosis index and quantity of mice offspring among the control group, the folic acid group, the cigarette smoke exposed group, and folic acid and cigarette smoke exposed group. The brain neurons apoptosis index of mice offspring whose mother was given with folic acid and cigarette smoke exposure during pregnancy was lower than that in those given with cigarette smoke exposure and were not given with folic acid. The quantity of brain neurons in mice offspring whose mother was given with folic acid and cigarette smoke exposure during pregnancy was higher than in mice exposed to cigarette smoke but not given with folic acid.

\section{REFERENCES}

Ginting JD (2013). Efek paparan berbagai jenis asap rokok terhadap usia kehamilan induk mencit, berat badan lahir dan intelektual anak mencit Mus musculus (Swiss webster). A thesis. Bandung, Universitas Kristen Maranatha

Istiadjid MES (2004). Pengaruh defisiensi folat terhadap fertilitas induk dan kualitas janin tikus. Jurnal kedokteran Brawijaya 20

Lewis CJ, Crane NT, Wilson DB, Yetley EA (1999). Estimated folate intakes: data updated to reflect food fortification, increased bioavailability, and dietary supplement use. The American Journal of Clinical Nutrition 70, 198-207

Ministry of Health (2015). Rokok illegal merugikan bangsa dan negara. Kementrian kesehatan RI. Available from http://www.Ministry of Health.go.id/ article/view/15060900001/rokok-illegal-merugikanbangsa-dan-negara.html. Accessed March 23, 2016

Mishra KP, Dayal R, Singh A, Pandey A (2014). Reactive oxygen species as mediator of tumor radio- 
sensitivity. Journal of cancer research and therapeutics $10,811-8$

Ramadhan (2012). Hubungan ibu hamil perokok pasif dengan kejadian BBLR di Badan Layanan Umum Daerah RSUB Meuraxa Banda Aceh. Jurnal Ilmiah Stikes U'budiyah. Aceh 1

Riset Kesehatan Dasar (2013). Riset kesehatan dasar 2013. Kementrian Kesehatan RI
Selhub J, Morris MS, Jacques PF, Rosenberg IH (2009). Folate-vitamin B-12 interaction in relation to cognitive impairment, anemia, and biochemical indicators of vitamin B-12 deficiency. The American Journal of Clinical Nutrition 89, 702S-706S

Wickström R (2007). Effects of nicotine during pregnancy: human and experimental evidence. Current Neuropharmacology. Sweden, Karolinska institutet 